(c) American Dairy Science Association, 2004.

\title{
Destruction of Mycobacterium paratuberculosis, Salmonella spp., and Mycoplasma spp. in Raw Milk by a Commercial On-Farm High-Temperature, Short-Time Pasteurizer
}

\author{
J. R. Stabel, ${ }^{1}$ S. Hurd, ${ }^{2}$ L. Calvente,${ }^{3}$ and R. F. Rosenbusch ${ }^{3}$ \\ ${ }^{1}$ USDA-ARS, National Animal Disease Center, Bacterial Diseases of Livestock Research Unit, Ames, IA 50014 \\ ${ }^{2}$ Preharvest Food Safety and Enteric Diseases Research Unit, Ames, IA 50010 \\ ${ }^{3}$ lowa State University, College of Veterinary Medicine, Ames 50014
}

\begin{abstract}
The 2002 NAHM's Dairy Survey indicated that $87.2 \%$ of dairy farms in the United States feed waste milk to their neonatal calves. Although cost-effective, this practice can lead to increased calf morbidity and mortality due to ingestion of pathogenic agents. In an effort to reduce the risk of infection, dairy producers are implementing on-farm pasteurization of the waste milk as a control procedure before feeding the milk to calves. In the present study, the efficacy of a commercial hightemperature, short-time (HTST) on-farm pasteurizer unit to destroy Mycobacterium paratuberculosis, Salmonella enterica spp., and Mycoplasma spp. in raw milk was evaluated. Replicate experiments were run for 3 isolates of M. paratuberculosis, 3 serovars of Salmonella (derby, dublin, typhimurium); and 4 species of Mycoplasma (bovis, californicum, canadense, serogroup 7) at 2 different levels of experimental inoculation. In addition, HTST pasteurization experiments were performed on colostrum experimentally inoculated with $M$. paratuberculosis. After culture of the pasteurized milk samples, no viable M. paratuberculosis, Salmonella, or Mycoplasma were recovered, regardless of species, strain, or isolate. Pasteurization of colostrum was also effective in the destruction of $M$. paratuberculosis but resulted in an average $25 \%$ reduction in colostral immunoglobulin. These results suggest that HTST pasteurization is effective in generating a safer product to feed to young calves.
\end{abstract}

(Key words: waste milk, pasteurization, neonatal calf)

Abbreviation key: HEYM = Herrold's egg yolk medium.

\section{INTRODUCTION}

Waste milk is a major source of nutrition for neonatal calves on dairy farms in the United States. This was

Received February 3, 2004.

Accepted February 26, 2004

Corresponding author: J. R. Stabel; e-mail: jstabel@nadc. ars.usda.gov. recently documented in a survey conducted by the National Health Monitoring System (NAHMS) that reported $87.2 \%$ of United States dairy farms feed waste milk to their neonatal calves (USDA, 2002). Although cost effective, this practice can lead to increased calf morbidity and mortality due to ingestion of pathogenic agents. It has been demonstrated that infected cows shed viable Mycobacterium paratuberculosis and Salmonella spp. in their colostrum and milk (Smith et al., 1989; Spier et al., 1991; Sweeney et al., 1992; Streeter et al., 1995). Contamination of milk from fecal matter containing either M. paratuberculosis or Salmonella shed by infected dams is another potential method of disease transmission from dam to calf. In addition, waste milk from mastitic cows may harbor mycoplasma agents that are primary causes of calf respiratory problems (Butler et al., 2000; Gonzalez and Wilson, 2003). The presence of these pathogens on dairy farms results in a major management problem for producers feeding waste milk to their calves. A recommendation for controlling the spread of infectious disease within a herd is to feed colostrum from noninfected dams or milk replacer. However, this recommendation creates an additional expense to a producer who must dump the waste milk and purchase commercial sources of colostrum or replacer products. Today, more producers are willing to implement control measures such as on-farm pasteurization of waste milk to destroy potential pathogens. This practice improves their long-range economic outlook by reducing losses due to calf morbidity and cost-outlay for commercial products. The effectiveness of an on-farm batch pasteurizer unit $\left(65.5^{\circ} \mathrm{C}\right.$ for $\left.30 \mathrm{~min}\right)$ was demonstrated to destroy $M$. paratuberculosis in waste milk (Stabel, 2001). On-farm pasteurization of waste milk held at $65^{\circ} \mathrm{C}$ for 10 min also destroyed common mastitic mycoplasma such as Mycoplasma bovis, M. californicum, and M. canadense (Butler et al., 2000). In the present study, the efficacy of a commercial HTST pasteurizer unit in the destruction of $M$. paratuberculosis, Salmonella spp., and Mycoplasma spp. in raw milk and $M$. paratuberculosis in colostrum was evaluated. 


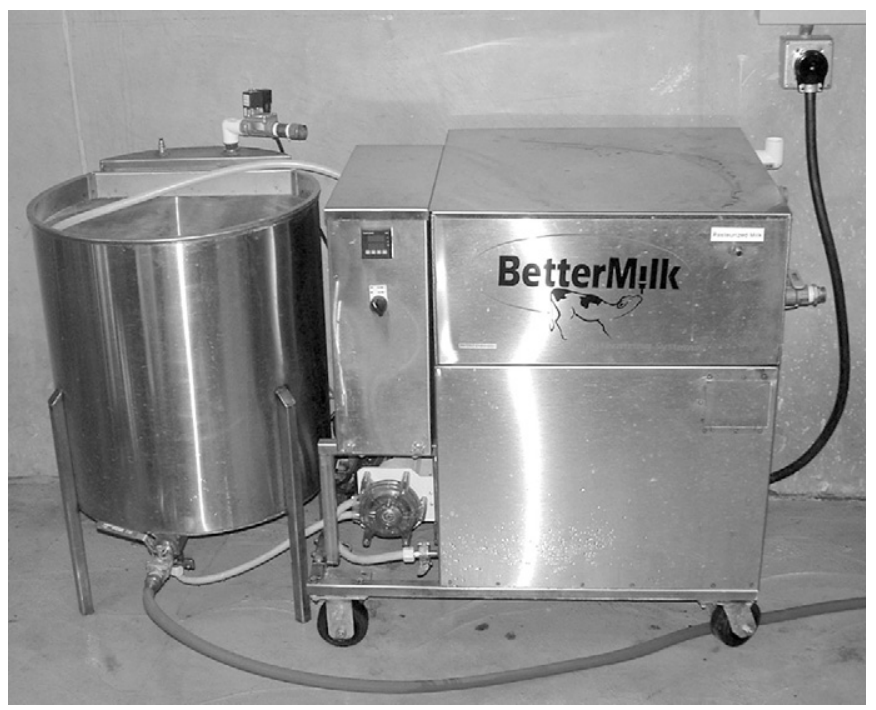

Figure 1. Bettermilk commercial high-temperature, short-time (HTST) pasteurizer unit (Bettermilk, Inc., Winona, MN).

\section{MATERIALS AND METHODS}

Experimental protocol. A commercial HTST pasteurizer unit (Bettermilk, Inc., Winona, MN) (Figure 1) was utilized to evaluate the efficacy of pasteurization in the destruction of $M$. paratuberculosis, Salmonella spp., and Mycoplasma spp. in raw milk. Fresh raw milk was obtained from Jersey cows housed at the National Animal Disease Center, Ames, IA, on the day of each experimental run. Twelve liters of raw milk were used for each experiment. An aliquot of fresh milk was reserved from the $12 \mathrm{~L}$ prior to each experiment to serve as a negative control. The remainder of the milk was placed in the holding vessel of the pasteurizer unit and inoculated with the appropriate level of pathogen. After careful mixing, an aliquot was reserved to serve as a nonheated positive control. The milk was then subjected to the standard protocol of heat treatment at $71.7^{\circ} \mathrm{C}$ for $15 \mathrm{~s}$. Upon completion of the cool-down at ambient temperature, samples were collected at 2,3 , and 4 min.

Colostrum was treated at temperatures ranging between 64 and $71.7^{\circ} \mathrm{C}$, then it was drained into stainless steel buckets and allowed to sit at ambient temperature for $30 \mathrm{~min}$. Samples of colostrum were obtained at times $0,10,20$, and 30 min during this period after pasteurization for culture. A negative control colostrum sample was obtained before inoculation of the colostrum with $M$. paratuberculosis, and a positive control sample was taken before heat treatment of the inoculated colostrum.

Mycobacterium paratuberculosis inoculation of milk and colostrum. Three isolates of $M$. paratubercu- losis were selected for evaluation in this study; strain 19698, a well-characterized laboratory strain originally isolated at the National Animal Disease Center from a cow with clinical Johne's disease; and strains 167 and 6112 , both propagated from primary isolations from cows with clinical disease that were necropsied at the National Animal Disease Center. Strain 19698 had been passed multiple times and was laboratory adapted, whereas strains 167 and 6112 had been passed 2 and 3 times, respectively. Two inoculum levels were evaluated for each strain of $M$. paratuberculosis: $10^{2}$ and $10^{6} \mathrm{cfu} / \mathrm{mL}$ of milk. Strains of $M$. paratuberculosis were propagated in Middlebrook 7H9 medium (Becton Dickinson, Cockeysville, MD) supplemented with $2 \mathrm{mg} /$ L of mycobactin J (Allied Monitor, Fayette, MO) and $10 \%$ oleic acid-albumin-dextrose complex enrichment (Difco, Detroit, MI) plus 0.05\% Tween 80 (Sigma Chemical Co., St. Louis, MO) until log phase of growth $\left(\mathrm{A}_{540 \mathrm{~nm}}=0.2\right.$ to 0.4$)$ was attained. Cells were harvested by centrifugation at $10,000 \times \mathrm{g}$ for $20 \mathrm{~min}$, washed with $1 \times$ PBS, $0.01 M, \mathrm{pH} 7.4$ ), and then resuspended to the appropriate concentration to achieve the high $\left(10^{6}\right)$ and low level $\left(10^{2}\right)$ of inoculum when added to the raw milk. Three replicates of each experiment (strain and inoculum level) were performed. Frozen colostrum was obtained from noninfected dairy cows on-site and from a farm in Minnesota with no history of Johne's disease. Only one isolate of $M$. paratuberculosis (strain 19698) at a concentration of $10^{5}$ was utilized in the colostrum experiments.

Culture of M. paratuberculosis from milk and colostrum. After heat treatment, control and test samples were centrifuged in 50-mL polypropylene tubes at $1200 \times \mathrm{g}$ for $30 \mathrm{~min}$ at $4^{\circ} \mathrm{C}$. The whey was discarded, and remaining pellet and cream fractions were resuspended in $1 \mathrm{~mL}$ of $1 \times$ PBS. This suspension was further diluted 10-fold in PBS. The original suspension and the diluted suspension $(100 \mu \mathrm{L}$ each) of each sample were inoculated in duplicate onto Herrold's egg yolk medium (HEYM) as previously described (Stabel, 2001). Samples were incubated at $37^{\circ} \mathrm{C}$, and cfu were recorded at 4,8 , and 26 wk. Colonies were confirmed as $M$. paratuberculosis by nested PCR and acid-fast stain. A suspect colony was picked using a sterile disposable loop and placed into 1-mL TE buffer (10 $\mathrm{m} M$ Tris-HCl, $\mathrm{pH} 8.0$; $1 \mathrm{~m} M$ EDTA, pH 8.0), and PCR analysis was performed as previously described (Stabel et al., 2002). Smears of suspect colonies were dried onto glass slides and examined after Ziehl-Neelsen staining for the presence of acid-fast bacteria.

Milk sample suspensions and their dilutions $(500 \mu \mathrm{L})$ were also inoculated into BACTEC medium (BectonDickinson,Franklin Lakes, NJ) containing $0.1 \mathrm{~mL}$ of mycobactin J, $1 \mathrm{~mL}$ of 50\% egg yolk suspension (Difco) 
and $0.1 \mathrm{~mL}$ of PANTA antibiotic supplement (BectonDickinson). Samples were incubated at $37^{\circ} \mathrm{C}$, and growth was monitored each week for $8 \mathrm{wk}$. A growth index greater than 30 was indicative of bacterial respiration and growth (Damato and Collins, 1990).

Colostral immunoglobulin. Total IgG in colostrum samples was determined in pre- and postpasteurization samples ( $\mathrm{T}=30 \mathrm{~min}$ after heat treatment) using the Bovine IgG Vet-RID kit (Bethyl Laboratories, Montgomery, TX). Colostrum samples were diluted 1:10 with sterile water and $5 \mu \mathrm{L}$ of diluted sample was placed in the test wells on the plate. Bovine IgG standards $(5 \mu \mathrm{L}$; 625,2500 , and $5000 \mathrm{mg} / \mathrm{mL}$ ) were run on each plate concurrently. Samples and standards were allowed to incubate at room temperature for $18 \mathrm{~h}$ according to the manufacturer's recommendation. The preciptin ring diameters of the reference standards, and test samples were measured to the nearest millimeter. A reference curve was constructed and utilized to determine the concentration of IgG in the test samples.

Salmonella samples and culture. Three serovars of S. enterica were obtained from cattle: S. dublin, $S$. derby, and $S$. typhimurium. Briefly, $1 \mathrm{~mL}$ of an overnight culture of Salmonella spp. was inoculated into $100 \mathrm{~mL}$ of lactose broth (EM Science, Darmstadt, Germany). Cultures were expanded at $37^{\circ} \mathrm{C}$ while shaking at $220 \mathrm{rpm}$ for $3.5 \mathrm{~h}$. Cultures were centrifuged at $18,000 \times g$ for $20 \mathrm{~min}$, and the pellet resuspended in $1 \times$ PBS to the desired concentration. Two inoculum levels were evaluated for each serovar of Salmonella: $10^{2}$ and $10^{6} \mathrm{cfu} / \mathrm{mL}$ of milk. Three replicates of each experiment (serovar and inoculum level) were performed. Negative (uninoculated milk) and positive (inoculated milk) control samples were taken in each experiment and cultured for the specific serovar of Salmonella.

After heat treatment, samples were direct plated (100 $\mu \mathrm{L}$ of milk) onto XLT4 (Becton-Dickinson, Sparks, MD; S. derby; S. typhimurium) or Chromogar (CHROMagar, Paris, France; S. dublin) and incubated for $24 \mathrm{~h}$ at $37^{\circ} \mathrm{C}$. On d 2, suspect colonies were picked, streaked onto Rambach agar (CHROMagar), and incubated for $24 \mathrm{~h}$ at $37^{\circ} \mathrm{C}$. After incubation, a BBL crystal microbial identification sytem (Becton-Dickinson) was run on any suspect colonies. In addition, samples were enriched by adding $1 \mathrm{~mL}$ of milk to each of the following: $9 \mathrm{~mL}$ of tetrathionate broth (Becton-Dickinson; TET) and $9 \mathrm{~mL}$ of buffered peptone water (Remel, Lenexa, KS; BPW). Samples were incubated at $37^{\circ} \mathrm{C}$ for $24 \mathrm{~h}$, then $0.1 \mathrm{~mL}$ of the enriched samples were transferred, respectively, to $10 \mathrm{~mL}$ of Rappaport-Vassiliadis medium (Becton Dickinson). Samples were further incubated at $42^{\circ} \mathrm{C}$ for $24 \mathrm{~h}$. The same protocol as described above was followed for direct plating of samples by plating on XLT4 agar or Chromagar (S. dublin) and brilliant green sulfa agar (all from Becton Dickinson), followed by Rambach agar, and BBL crystal analysis.

Mycoplasma samples and culture. Four major species of Mycoplasma that have been implicated in bovine mastitis were evaluated in this study, including: M. bovis, strains Jasper, UCD9, and 1135-6; M. californicum, strains ST6, and Cs 687; $M$. canadense, strain 275C; and $M$. serogroup 7, strains PG50 and Cs 826C. Mycoplasma strains were propagated by growing in Friis broth (Knudtson et al., 1986) containing $200 \mu \mathrm{g} /$ $\mathrm{mL}$ of bacitracin, $100 \mu \mathrm{g} / \mathrm{mL}$ of thalium acetate, and 67 $\mu \mathrm{g} / \mathrm{mL}$ cefoperazone, to inhibit bacterial growth. After $48 \mathrm{~h}$ of incubation at $37^{\circ} \mathrm{C}$, each broth culture was sampled with a sterile toothpick and streaked onto a Friis agar plate containing the same concentrations of bacterial inhibitors to check growth of the Mycoplasma. Cells were harvested by centrifugation at $25,000 \times g$ for 20 min at $4^{\circ} \mathrm{C}$, washed twice with PBS, then resuspended to $10 \times$ of the original concentration. Suspensions were passed 3 times through a 25-g needle to disperse clumps. After addition of $10 \%$ fetal bovine serum, suspensions were snap-frozen and stored at $-70^{\circ} \mathrm{C}$. Aliquots of each strain were thawed prior to each experiment and added to the raw milk to achieve the appropriate concentration. Two inoculum levels were evaluated for each strain of Mycoplasma: generally, $10^{2}$ and $10^{6} \mathrm{cfu} / \mathrm{mL}$ of milk. Two replicates of each experiment (strain and inoculum level) were performed. Negative (uninoculated milk) and positive (inoculated milk) control samples were taken in each experiment and cultured for the specific strain of Mycoplasma. Mycoplasma canadense, strain $275 \mathrm{C}$, was demonstrated to be the most heat resistant strain of mycoplasma in a previous pasteurization study.

After heat treatment, samples were cultured by inoculating $100 \mu \mathrm{L}$ into $900 \mu \mathrm{L}$ of Friis broth in multiwell plates, and plates were incubated at $37^{\circ} \mathrm{C}$ in $2 \% \mathrm{CO}_{2}$ atmosphere. After $48 \mathrm{~h}$ of incubation, each broth culture was sampled with a sterile toothpick and streaked onto a Friis agar plate containing bacterial inhibitors as previously described. Plates were incubated for 2 to $3 \mathrm{~d}$ at $37^{\circ} \mathrm{C}$ in $2 \% \mathrm{CO}_{2}$, and then examined under low magnification for the presence of mycoplasma colonies on the streaked areas.

\section{RESULTS}

The temperature changes over time during standard operation of the HTST pasteurizer unit are depicted in Table 1. Temperature of the raw milk was $19^{\circ} \mathrm{C}$ at time 0 and ascended rapidly to a temperature of $61.7^{\circ} \mathrm{C}$ by 1 min of circulation through the unit. The set temperature of $71.7^{\circ} \mathrm{C}$ was reached after 9 min of circulation, at which time it was diverted into the heating tube for 
Table 1. Time and temperature control $\left({ }^{\circ} \mathrm{C}\right)$ displays during HTST processing of raw milk using the Bettermilk (Bettermilk, Inc., Winona, MN) pasteurizer unit.

\begin{tabular}{lllll}
\hline & $\begin{array}{l}\text { Time } \\
(\mathrm{min})\end{array}$ & $\begin{array}{l}\text { Milk } \\
\text { holding } \\
\text { tank }\end{array}$ & $\begin{array}{l}\text { Entry into } \\
\text { heating tube }\end{array}$ & $\begin{array}{l}\text { Product } \\
\text { temperature }\end{array}$ \\
\hline Prepasteurization & 0 & 26 & & 20 \\
& 1 & 26 & & 62 \\
& 2 & 32 & & 57 \\
& 3 & & & 57 \\
& 4 & 39 & 62 & 62 \\
& 5 & & & 65 \\
& 6 & & 67 & 68 \\
Postpasteurization & 7 & & 71 & 69 \\
& 8 & & 72 & 71 \\
& 9 & & & 72 \\
Rinse & 2 & & & 72 \\
\hline & 3 & & & 72 \\
& & & 65 & \\
\hline
\end{tabular}

a 15-s period. Temperature of the unit held at the set temperature with only minor fluctuation of 1 to $2^{\circ} \mathrm{C}$ after the milk product was treated.

Serial titration of positive control and test samples was performed for milk inoculated with $M$. paratuberculosis to allow optimal detection of potential survivors. The detection limits of the positive controls for the HEYM solid medium and the BACTEC liquid medium system are depicted in Table 2. On HEYM agar medium we were able to detect between 1 to $10 \mathrm{cfu} / \mathrm{mL}$ of milk. The BACTEC liquid system detected $1 \mathrm{cfu} / \mathrm{mL}$ after 6 wk of incubation. Therefore, the sensitivity of detection of $M$. paratuberculosis was very high, and it was unlikely that any survivors were missed.

Results of the heat treatment of the raw milk containing $M$. paratuberculosis, Salmonella spp., and $M y$ coplasma spp. indicate that the commercial HTST unit is effective in the destruction of these pathogens, regardless of inoculum level (Tables 3, 4, and 5). The negative control milk sample (nonheated, uninoculated raw milk) was culture positive on several experimental runs with the Salmonella strains, but upon subculture this proved to be a contaminant. No evidence of contaminants was indicated in the heated milk samples.

Heat treatment of colostrum in the lower temperature range $\left(63.9\right.$ to $\left.66.7^{\circ} \mathrm{C}\right)$ did not immediately destroy the $M$. paratuberculosis present (Table 6; time 0). However, recovery of $M$. paratuberculosis from colostrum was reduced by $2 \log _{10}$ after $10 \mathrm{~min}$ of incubation in the buckets and achieved a nadir of $<3 \mathrm{cfu} / \mathrm{mL}$ of milk after $30 \mathrm{~min}$. Increasing the temperature range $(68.3$ to $70.8^{\circ} \mathrm{C}$ ) completely abrogated recovery of viable $M$. paratuberculosis from the colostrum, even at time 0 (Table 6). Total IgG was reduced by HTST pasteurization of colostrum regardless of temperature regime (Table 7). Initial colostral IgG averaged $68.4 \mathrm{mg} / \mathrm{mL}$ (range: 62 to $78 \mathrm{mg} / \mathrm{mL}$ ) across all experiments. At the lower temperature range, a $22 \%$ reduction in colostral $\mathrm{IgG}$ was observed after $30 \mathrm{~min}$ in the bucket. Colostral IgG decreased even more (27\%) after treatment of colostrum at the higher temperatures. Postpasteurization colostral immunoglobulin concentration averaged 51.3 and

Table 2. Titration of viable Mycobacteria paratuberculosis from high positive control sample $\left(1 \times 10^{5} \mathrm{cfu} /\right.$ $\mathrm{mL}$ ) on BACTEC $^{1}$ and $\mathrm{HEYM}^{2}$ media.

\begin{tabular}{|c|c|c|c|c|c|c|}
\hline \multirow[b]{2}{*}{ Culture medium } & \multicolumn{6}{|c|}{ Weeks of incubation } \\
\hline & 1 & 3 & 4 & 6 & 7 & 8 \\
\hline \multicolumn{7}{|l|}{ BACTEC } \\
\hline $\begin{array}{l}\text { No dilution } \\
10^{-1} \\
10^{-2} \\
10^{-3} \\
10^{-4} \\
10^{-5} \\
10^{-6}\end{array}$ & $\begin{array}{r}999 \\
89 \\
16 \\
9 \\
6 \\
8 \\
7\end{array}$ & $\begin{array}{r}999 \\
876 \\
999 \\
39 \\
3 \\
5 \\
8\end{array}$ & $\begin{array}{r}999 \\
999 \\
999 \\
172 \\
7 \\
3 \\
3\end{array}$ & $\begin{array}{r}999 \\
999 \\
999 \\
999 \\
144 \\
303 \\
39\end{array}$ & $\begin{array}{l}999 \\
999 \\
999 \\
999 \\
999 \\
999 \\
999\end{array}$ & $\begin{array}{l}999 \\
999 \\
999 \\
999 \\
999 \\
999 \\
999\end{array}$ \\
\hline HEYM & 4 & 8 & 24 & & & \\
\hline No dilution & $\mathrm{C}$ & $\mathrm{C}$ & $\mathrm{C}$ & & & \\
\hline $10^{-1}$ & $\mathrm{C}$ & $\mathrm{C}$ & $\mathrm{C}$ & & & \\
\hline $10^{-2}$ & $\mathrm{~T}$ & $\mathrm{~T}$ & $\mathrm{~T}$ & & & \\
\hline $10^{-3}$ & $\mathrm{~T}$ & $\mathrm{~T}$ & $\mathrm{~T}$ & & & \\
\hline $10^{-4}$ & 50 & 64 & 65 & & & \\
\hline $10^{-5}$ & 1 & 2 & 2 & & & \\
\hline $10^{-6}$ & 0 & 0 & 0 & & & \\
\hline
\end{tabular}

\footnotetext{
${ }^{1}$ The cut-off for a positive growth index for the detection of $M$. paratuberculosis in BACTEC medium is designated as $>30$; GI $=999$ indicates overgrowth in the media.

${ }^{2}$ Designations are $\mathrm{C}=$ contamination and $\mathrm{T}=$ too numerous to count (100 cfu/slant). HEYM $=$ Herrold's egg yolk medium.
} 
Table 3. Destruction of Mycobacterium paratuberculosis after HTST heat treatment at $71.7^{\circ} \mathrm{C}$ for $15 \mathrm{~s}$.

\begin{tabular}{llllll}
\hline & \multicolumn{2}{c}{ High level of inoculum } & & \multicolumn{2}{c}{ Low level of inoculum } \\
\cline { 2 - 3 } \cline { 5 - 6 } Strain & Prepasteurization & Postpasteurization & & Prepasteurization & Postpasteurization \\
\hline \multirow{2}{*}{19698 (lab) } & $8.2 \times 10^{4}$ & ND $^{1}$ & ND & $6.0 \times 10^{1}$ & ND \\
& $7.8 \times 10^{4}$ & ND & & $1.3 \times 10^{2}$ & ND \\
& $2.3 \times 10^{3}$ & ND & & $2.3 \times 10^{2}$ & ND \\
167 (wild) & $1.9 \times 10^{5}$ & ND & $6.3 \times 10^{2}$ & ND \\
& $2.1 \times 10^{5}$ & ND & & $4.2 \times 10^{2}$ & ND \\
& $2.2 \times 10^{4}$ & ND & $8.2 \times 10^{2}$ & ND \\
6112 (wild) & $1.9 \times 10^{6}$ & ND & $5.4 \times 10^{1}$ & ND \\
& $5.9 \times 10^{5}$ & ND & $4.3 \times 10^{2}$ & ND \\
& $6.8 \times 10^{5}$ & & $2.1 \times 10^{2}$ & ND \\
\hline
\end{tabular}

${ }^{1} \mathrm{ND}=$ Not detected.

$45.3 \mathrm{mg} / \mathrm{mL}$, respectively, for the low and high temperature range.

\section{DISCUSSION}

We were able to demonstrate in the present study that HTST pasteurization is effective in the destruction of M. paratuberculosis, Salmonella spp., and Mycoplasma spp. in waste milk. Previously, we reported complete destruction of $M$. paratuberculosis occurred in waste milk treated at $65.5^{\circ} \mathrm{C}$ for 30 min using an onfarm batch pasteurizer (Stabel, 2001). Indeed, there was no recovery of any viable $M$. paratuberculosis organisms before the unit reached $65.5^{\circ} \mathrm{C}$, indicating that progressive heating of the substrate during the period of time required to reach the target temperature can effectively reduce the presence of pathogenic contamination as well. Similarly, heat treatment of discard mycoplasma-containing mastitic milk at $65^{\circ} \mathrm{C}$ for $2 \mathrm{~min}$ in a batch pasteurizer unit destroyed $M$. bovis and $M$. californicum present (Butler et al., 2000). Milk was held at $65^{\circ} \mathrm{C}$ for $10 \mathrm{~min}$ before destruction of $M$. canadense was confirmed. Raising the temperature to $70^{\circ} \mathrm{C}$ shortened the time required for inactivation to $1 \mathrm{~min}$ for $M$. bovis and M. californicum and 3 min for $M$. canadense. The results from that study demonstrate that batch pasteurization was effective for all 3 species of Mycoplasma, although $M$. canadense was more heat-resistant than the other 2 strains. Other studies have indicated that Mycoplasma was successfully destroyed if treated at $74^{\circ}$ to $76^{\circ} \mathrm{C}$ for 15 to $20 \mathrm{~s}$ (HTST) or $65.5^{\circ} \mathrm{C}$ for 30 min (batch) (Bray et al., 2001).

Although there are no published studies on record evaluating pasteurization of waste milk for the destruction of Salmonella spp., it is recognized that IMI with S. dublin and S. typhimurium are problematic in some dairy herds and that some cows may excrete up to $10^{5}$ organisms per milliliter of milk (Ogilvie, 1986; Smith et al., 1989; Spier et al., 1991). Salmonellosis is a wellknown contributor to the morbidity and mortality of neonatal calves, and feeding raw waste milk may play a significant role in exacerbating transmission of this infection between cows and calves.

Batch pasteurization has proven effective for the destruction of M. paratuberculosis and Mycoplasma and, therefore, can provide a clean product to feed to calves. This method of pasteurization also has the advantage that waste milk can be directly piped into the unit and

Table 4. Destruction of Salmonella spp. during HTST heat treatment at $71.7^{\circ} \mathrm{C}$ for $15 \mathrm{~s}$.

\begin{tabular}{|c|c|c|c|c|c|}
\hline \multirow[b]{2}{*}{ Species } & \multirow[b]{2}{*}{ Strain } & \multicolumn{2}{|c|}{ High level of inoculum } & \multicolumn{2}{|c|}{ Low level of inoculum } \\
\hline & & Prepasteurization & Postpasteurization & Prepasteurization & Postpasteurization \\
\hline S. derby & $\begin{array}{l}\text { NVSL } \\
2681 b\end{array}$ & $\begin{array}{l}2.0 \times 10^{6} \\
2.0 \times 10^{6} \\
2.0 \times 10^{6}\end{array}$ & $\begin{array}{l}\mathrm{ND}^{1} \\
\mathrm{ND} \\
\mathrm{ND}\end{array}$ & $\begin{array}{l}2.5 \times 10^{3} \\
1.5 \times 10^{3} \\
9.0 \times 10^{2}\end{array}$ & $\begin{array}{l}\text { ND } \\
\text { ND } \\
\text { ND }\end{array}$ \\
\hline S. dublin & $\begin{array}{l}\text { NVSL } \\
3129\end{array}$ & $\begin{array}{l}6.0 \times 10^{6} \\
9.0 \times 10^{6} \\
3.3 \times 10^{7}\end{array}$ & $\begin{array}{l}\text { ND } \\
\text { ND } \\
\text { ND }\end{array}$ & $\begin{array}{l}\mathrm{NP}^{2} \\
\mathrm{NP} \\
\mathrm{NP}\end{array}$ & $\begin{array}{l}\text { ND } \\
\text { ND } \\
\text { ND }\end{array}$ \\
\hline S. typhimurium & $\begin{array}{l}\text { NVSL } \\
5372\end{array}$ & $\begin{array}{l}2.1 \times 10^{7} \\
2.1 \times 10^{7} \\
2.0 \times 10^{7}\end{array}$ & $\begin{array}{l}\text { ND } \\
\text { ND } \\
\text { ND }\end{array}$ & $\begin{array}{l}\text { NP } \\
\text { NP } \\
\text { NP }\end{array}$ & $\begin{array}{l}\text { ND } \\
\text { ND } \\
\text { ND }\end{array}$ \\
\hline
\end{tabular}


Table 5. Destruction of Mycoplasma spp. during HTST heat treatment at $71.7^{\circ} \mathrm{C}$ for $15 \mathrm{~s}$.

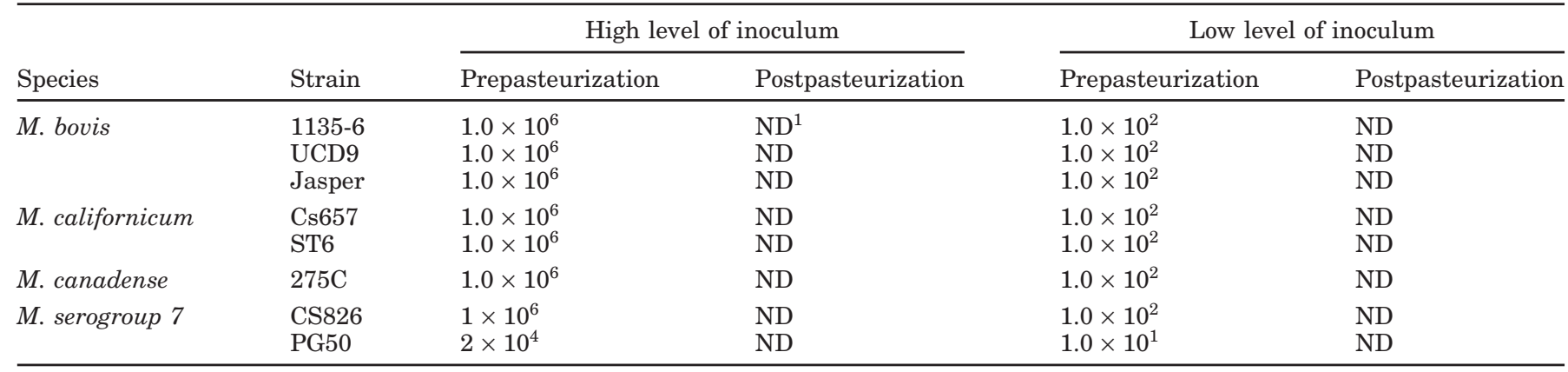

${ }^{1} \mathrm{ND}=$ Not detected

held until the producer is ready to perform the heat treatment of the milk. However, it typically required about $1.5 \mathrm{~h}$ for the complete heating process, requiring nearly $1 \mathrm{~h}$ for the unit to reach the target temperature, followed by 30 min of heat treatment at the hold temperature. Commercial HTST pasteurization units for use on-farm may be more efficient processing tools for daily pasteurization of waste milk. The HTST unit utilized in the present study took minimal time $(9 \mathrm{~min})$ to reach the target temperature, and the product required only $15 \mathrm{~s}$ for complete inactivation of the pathogens tested due to the flow-through processing method. For optimal performance and maintenance of the machine, it was recommended that the unit be cleaned after each run. However, the cleaning cycle was completely automatic and required only $20 \mathrm{~min}$. Therefore, the time and labor required for operation of this unit was significantly reduced compared to the batch pasteurization unit. However, both methods are equally effective in reducing potential pathogens in waste milk and can be recommended for the practice of controlling neonatal infections within a herd.

A major concern of producers is whether there are economic benefits associated with pasteurization of waste milk or colostrum. In addition, there is concern about the reduction in immunoglobulin content in colostrum that has been heat-treated. We demonstrated an average reduction in colostral IgG of $25 \%$ regardless of heat treatment regime. Similar results were reported after heat treatment of colostrum in 57-L batches for $30 \mathrm{~min}$ at $63^{\circ} \mathrm{C}$ (Godden et al., 2003). Pasteurization has reduced the immunologlobulin content of colostrum to varying degrees, although it is not known if this affects the health of the calf (Meylan et al., 1995; Godden et al., 2003). Godden et al. (2003) demonstrated that feeding $2 \mathrm{~L}$ of pasteurized colostrum to calves at the first feeding resulted in significantly lower serum IgG concentrations $(9.7 \mathrm{mg} / \mathrm{mL})$ compared to calves fed unpasteurized colostrum $(19.1 \mathrm{mg} / \mathrm{mL})$. Alternatively, when calves were fed $4 \mathrm{~L}$ at the first feeding, there was no difference in serum IgG between the 2 groups (16.1 vs. $13.5 \mathrm{mg} / \mathrm{mL}$ for unpasteurized and pasteurized colostrum, respectively). A study comparing the performance of calves fed pasteurized or nonpasteurized colostrum and waste milk found that feeding pasteurized products to calves significantly increased their mean weight gain (Jamaluddin et al., 1996). Treatment costs for illness and mortality rates were reduced for calves fed the pasteurized milk and colostrum, whereas costs of pasteurization were negliglible, suggesting a significant economic advantage for producers.

Producers may be wary of pasteurizing colostrum with an HTST unit due to potential gelling of the product within the tubing during the heating process. In

Table 6. Recovery of Mycobacterium paratuberculosis in colostrum after HTST heat treatment at a low and high temperature range for $15 \mathrm{~s}^{1}$

\begin{tabular}{|c|c|c|c|c|}
\hline \multirow{2}{*}{$\begin{array}{l}\text { Time after } \\
\text { heat treatment } \\
\text { (min) }\end{array}$} & \multicolumn{2}{|c|}{ Low temperature $\left(63.9-66.7^{\circ} \mathrm{C}\right)$} & \multicolumn{2}{|c|}{ High temperature $\left(68.3-70.8^{\circ} \mathrm{C}\right)$} \\
\hline & $\begin{array}{l}\text { Milk temperature } \\
\text { in the bucket }\end{array}$ & $\mathrm{cfu} / \mathrm{mL}$ & $\begin{array}{l}\text { Milk temperature } \\
\text { in the bucket }\end{array}$ & $\mathrm{cfu} / \mathrm{mL}$ \\
\hline $\mathrm{T}=0$ & $62.8^{\circ} \mathrm{C}$ & $1.4 \times 10^{4}$ & $65^{\circ} \mathrm{C}$ & $<1$ \\
\hline $\mathrm{T}=10$ & $56.1^{\circ} \mathrm{C}$ & $2.3 \times 10^{2}$ & $61.7^{\circ} \mathrm{C}$ & $\mathrm{ND}^{2}$ \\
\hline $\mathrm{T}=20$ & $53.3^{\circ} \mathrm{C}$ & 4.1 & $56.7^{\circ} \mathrm{C}$ & ND \\
\hline $\mathrm{T}=30$ & $51.7^{\circ} \mathrm{C}$ & 2.2 & $54.7^{\circ} \mathrm{C}$ & ND \\
\hline
\end{tabular}

${ }^{1}$ Results are averaged from 3 replicate runs.

${ }^{2} \mathrm{ND}=$ Not detected. 
Table 7. Colostral IgG concentrations $(\mathrm{mg} / \mathrm{mL})$ before and after HTST pasteurization.

\begin{tabular}{|c|c|c|c|c|}
\hline \multirow{2}{*}{$\begin{array}{l}\text { Time after } \\
\text { heat treatment } \\
(\mathrm{min})\end{array}$} & \multicolumn{2}{|c|}{ Low temperature $\left(63.9-66.7^{\circ} \mathrm{C}\right)$} & \multicolumn{2}{|c|}{ High temperature $\left(68.3-70.8^{\circ} \mathrm{C}\right)$} \\
\hline & $\begin{array}{l}\text { Milk temperature } \\
\text { in the bucket }\end{array}$ & $\operatorname{IgG}(\mathrm{mg} / \mathrm{mL})$ & $\begin{array}{l}\text { Milk temperature } \\
\text { in the bucket }\end{array}$ & $\operatorname{IgG}(\mathrm{mg} / \mathrm{mL})$ \\
\hline $\begin{array}{l}\mathrm{T}=0 \\
\mathrm{~T}=30\end{array}$ & $62.8^{\circ} \mathrm{C}$ & 67.3 & $65.0^{\circ} \mathrm{C}$ & 62.0 \\
\hline
\end{tabular}

preliminary experiments at a set temperature of $71.7^{\circ} \mathrm{C}$ (range 68 to $72^{\circ} \mathrm{C}$ ), there was no gelling of the product within the holding tube, but gelling was observed when the product was allowed to sit in the bucket. To circumvent this problem, subsequent experiments were designed to run at lower temperatures than the typical set point of $71.7^{\circ} \mathrm{C}$. After heating, the product was diverted into stainless steel buckets rather than running through the cooling tubes. Allowing the heated product to sit an additional $30 \mathrm{~min}$ in the bucket provided a heat sink that effectively increased the destruction of $M$. paratuberculosis. When the experiments were conducted with the temperature ranges reported within this paper $\left(63.9\right.$ to $66.7^{\circ} \mathrm{C}$ and 68.3 to $\left.70.8^{\circ} \mathrm{C}\right)$, the product remained fluid and did not coagulate even after sitting in the buckets for $30 \mathrm{~min}$.

In conclusion, HTST pasteurization of raw milk is effective for the destruction of $M$. paratuberculosis, Salmonella spp., and Mycoplasma spp. in raw milk and effectively destroys $M$. paratuberculosis in colostrum. This information provides dairy producers with an alternative to purchasing commercial replacement products, resulting in reduced costs. More importantly, pasteurization of waste milk significantly reduces calf morbidity and helps break the transmission cycle of infectious pathogens on-farm.

\section{REFERENCES}

Bray, D. R., M. B. Brown, and G. A. Donovan. 2001. Mycoplasma again. Pages 52-60 in Proc. of the 38th Annu. Florida Dairy Production Conference, Gainesville, FL.

Butler, J. A., S. A. Sickles, C. J. Johanns, and R. F. Rosenbusch. 2000. Pasteurization of discard Mycoplasma mastitic milk used to feed calves: Thermal effects on various mycoplasma. J. Dairy Sci. 83:2285-2288.
Damato, J. J., and M. T. Collins. 1990. Growth of Mycobacterium paratuberculosis in radiometric, Middlebrook and egg-based media. Vet. Microbiol. 22:31-42.

Godden, S. M., S. Smith, J. M. Feirtag, L. R. Green, S. J. Wells, and J.P. Fetrow. 2003. Effect of on-farm commercial batch pasteurization of colostrum on colostrum and serum immunoglobulin concentrations in dairy calves. J. Dairy Sci. 86:1503-1512.

Gonzalez, R. N., and D. J. Wilson. 2003. Mycoplasmal mastitis in dairy herds. Vet. Clin. Food Anim. 19:199-221.

Jamaluddin, A. A., T. E. Carpenter, D. W. Hird, and M. C. Thurmond. 1996. Economics of feeding pasteurized colostrum and pasteurized waste milk to dairy calves. JAVMA 209:751-756.

Knudtson, W. U., D. E. Reed, and G. Daniels. 1986. Identification of Mycoplasmatales in pneumonic calf lungs. Vet. Microbiol. 11:79-91.

Meylan, M., M. Rings, W. P. Shulaw, J. J. Kowalski, S. Bech-Nielsen, and G. F. Hoffsis. 1995. Survival of Mycobacterium paratuberculosis and preservation of immunoglobulin $\mathrm{G}$ in bovine colostrum under experimental conditions simulating pasteurization. Am. J. Vet. Res. 57:1580-1585.

Ogilvie, T. H. 1986. The persistent isolation of Salmonella typhimurium from the mammary gland of a dairy cow. Can. Vet. J. 27:329-331.

Smith, B. P., D. G. Oliver, P. Singh, G. Dilling, P. A. Martin, B. P. Ram, L. S. Jang, N. Sharkov, J. S. Orsborn, and P. A. Marvin. 1989. Detection of Samonella dublin mammary gland infection in carrier cows, using an enzyme-linked immunosorbent assay for antibody in milk or serum. Am. J. Vet. Res. 50:1352-1360.

Spier, S. J., B. P. Smith, J. S. Cullor, H. J. Olander, L. Da Roden, and G. W. Dilling. 1991. Persistent experimental Salmonella dublin intramammary infection in dairy cows. J. Vet. Intern. Med. $5: 341-350$.

Stabel, J. R. 2001. On-farm batch pasteurization destroys Mycobacterium paratuberculosis in waste milk. J. Dairy Sci. 84:524-527.

Stabel, J. R., S. J. Wells, and B. A. Wagner. 2002. Relationships between fecal culture, ELISA, and bulk tank milk test results for Johne's disease in US dairy herds. J. Dairy Sci. 85:525-531.

Streeter, R. N., G. F. Hoffsis, S. Bech-Nielsen, W. P. Shulaw, and D. M. Rings. 1995. Isolation of Mycobacterium paratuberculosis from colostrum and milk of subclinically infected cows. Am. J. Vet. Res. 56:1322-1324.

Sweeney, R. W., R. H. Whitlock, and A. E. Rosenberger. 1992. Mycobacterium paratuberculosis cultured from milk and supramammary lymph nodes of infected asymptomatic cows. J. Clin. Microbiol. 30:166-171.

USDA. 2002. Part I: Reference of Dairy Health and Management in the United States, USDA:APHIS:VS, CEAH, National Animal Health Monitoring System, Fort Collins, CO. 